\title{
THE DIFFERENCE BETWEEN IFRS AND US GAAP IN FINANCIAL STATEMENT PRESENTATION
}

\author{
Saleh JAWARNEH
}

Department of Finance, Faculty of Economics, University of Miskolc, Hungary Saleh1jaw@gmail.com

\begin{abstract}
This paper meticulously studies the main differences between US GAAP and IFRS when it comes to the presentation of financial statements focusing on the balance sheet and income statement more than the cash flow statement. A real-life case study (of a company called Hydro) approach was applied to see the effect of using on the system over the other by numbers, and how far applying one system affect the result of each financial statement, the case study shows a practical conversion of US GAAP results to IFRS and how each system lists the financial statements next to each other. There are multiple similarities between US GAAP and IFRS when it comes to the presentation of financial statements, but there are some differences that affect what financial information is presented, how it is presented, and where it is presented. For example, regarding financial statement presentation, cosmetic differences include the use of the accounting equation $(A=L+S E)$ compared to $(A-S E=L)$, terminology, and order of liquidity. The study is solely based on secondary data collected from different reliable sources like Ernst and Young. The findings of this research indicate that there are some notable differences between US GAAP and IFRS in financial statement presentation, but they are not significant. Finally, bringing together both systems increase the comparability of accounting practices and results to investors, greater investor desire for cross-regional investment, lower capital cost, more efficient resource allocation; And even higher economic growth not only for companies and institutions but also for government, which can be done by setting limits on how much they can vary.
\end{abstract}

Keywords: Accounting Standards, IFRS, US GAAP, Accounting Harmonization

JEL classification: M40; M41; M48; E42

\section{Introduction}

Accounting has been developed since a long time ago, where every country has been interested in developing its own principles which can reflect the industry practices and contributions of accounting bodies established for this purpose, there have been leading countries in this area because of industrial development, including the United States of America, which knew a developed industrial sector in the beginnings of the last century which been reflected on the developing of the accounting profession (Unegbu, 2014).

Convergence of accounting standards has an advantage for listed companies in two respects: on the one hand, there is no need to prepare more financial statements, which saves large amounts, and on the other hand, due to financial comparability. Data is guaranteed. In this regard, under the 2002 Norwalk Agreement, the Financial Accounting Standards Board and the International 
Accounting Standards Board have decided that the U.S. Standards Board has decided that the U.S. Standards are close to the International Standards (Burlaud \& Baker, 2015). However, it seems that it will take many years for the two references to come close.

The main difference between IFRS and US GAAP is that US standards are rulesbased and IFRSs are principles. A rules-based standard does not mean that standards bodies did not apply principles to create them, but that rules play an important role in the implementation of the standard. As part of this debate, there is an important debate about principles-based standards and rules-based standards. Rules-based standards, the dominant approach of the FASB, attempt to anticipate and find solutions to all or most problems, while standards-based standards, the dominant approach of the IASB, are less prescriptive and based on objectives and principles to be followed. As a result, US GAAP consists of approximately 17,000 pages, while IFRS contains approximately 2,500 pages (Gibson, 2009).

Using different accounting frameworks in different areas becomes a problem for both companies and investors. To that end, it was necessary for countries to abandon their accounting frameworks and use one framework to reduce the problem of variation (UNITED NATIONS, 2008).

Both committees are guided by the conceptual framework (IASB for IFRS, U.S. GAAP for FASB) when establishing or revising new standards. As a result, the differences between them can contribute to differences in standards. In 2004, through the convergence of the two repositories (IFRS and US GAAP), the Financial Accounting Standards Board and the International Accounting Standards Board began working together to develop a common and improved conceptual framework that provides a basis for common standards. The project has eight steps, and the two bodies are currently working on the first four, The first phase was completed and resulted in the issuance of a conceptual framework that includes the objective of financial reporting and the qualitative characteristics of useful information, it seems that the harmonization of IFRS and U.S. GAAP is always a work in progress. (Smith, 2011)

\section{Literature Review}

Several papers attempted to determine the level of compliance between various accounting practices and the impact of adopting international standards on accounting harmonization.

Gordon al. (2011) used a large sample of companies reporting under both IFRS and GAAP compared to other studies. Form 156 firms are used, which adapts IFRS to GAAP for three years, 2004-2006. Their study continues the tradition of using numbers in financial statements to assess the adequacy of book quality and value. It is concluded that GAAP continues to differ from IFRS, showing "increasing information" in addition to IFRS numbers and that GAAP is more important in terms of "monetary stability" and value. They suggest that IFRS and GAAP are different, even in the recent past, when convergence was well advanced. They show that there are differences and, in this sense, complement the first of our three research objectives (Gordon, et al., 2011).

According to EY annual book, In terms of financial statement format, US GAAP and IFRS guidelines are quite comparable. A statement of financial position, a statement of profit and loss (income statement), a statement of comprehensive 
income (either a single continuous statement or two consecutive statements), a statement of cash flows, and accompanying notes to the financial statements are all included in a complete set of financial statements under both sets of standards. Both US GAAP and IFRS necessitate the presentation of changes in shareholders' equity. However, US GAAP permits the presentation of changes in shareholders' equity in the notes to the financial statements, but IFRS mandates the presentation of changes in shareholders' equity as a separate statement. Furthermore, unless under exceptional circumstances, both require the financial statements to be prepared on an accrual method of accounting. The ideas of materiality and consistency that companies must examine in producing their financial statements are comparable in IFRS and US GAAP. The degree of detailed instruction offered tends to be where the two sets of criteria differ. (EY, 2021)

Table 1: Financial statement presentation significant differences

\begin{tabular}{|c|c|c|}
\hline & US GAAP & IFRS \\
\hline $\begin{array}{l}\text { Financial periods } \\
\text { required }\end{array}$ & $\begin{array}{l}\text { A single year can be presented } \\
\text { in certain circumstances, while } \\
\text { comparative statement are } \\
\text { presented. On the other hand, } \\
\text { public companies must follow } \\
\text { SEC rules, which typically } \\
\text { require two most recent years. }\end{array}$ & $\begin{array}{l}\text { Comparative information } \\
\text { must be presented to } \\
\text { previous period, for all } \\
\text { amounts reported in } \\
\text { current period's financial } \\
\text { statement. }\end{array}$ \\
\hline $\begin{array}{l}\text { Layout of balance } \\
\text { sheet and income } \\
\text { statement }\end{array}$ & $\begin{array}{l}\text { Public companies must follow } \\
\text { the detailed regulations, there is } \\
\text { no general requirements with in } \\
\text { the US GAAP to prepare } \\
\text { balance sheet or income } \\
\text { statement. }\end{array}$ & $\begin{array}{l}\text { IFRS doesn't require } \\
\text { specific layout but } \\
\text { includes minimum line } \\
\text { items, and these are less } \\
\text { than the required by US } \\
\text { GAAP for public } \\
\text { companies. }\end{array}$ \\
\hline $\begin{array}{l}\text { Balance sheet- } \\
\text { presentation of } \\
\text { debt as current } \\
\text { versus noncurrent }\end{array}$ & $\begin{array}{l}\text { Debts in which there has been a } \\
\text { covenant violation may be } \\
\text { presented as non-current if } \\
\text { there is agreement by the } \\
\text { lender to waive the right to } \\
\text { claim payment more than one } \\
\text { year before the financial } \\
\text { statements are issued or made } \\
\text { available for issuance. }\end{array}$ & $\begin{array}{l}\text { Debt related to breach of } \\
\text { the covenant violation } \\
\text { must be provided as } \\
\text { current unless the lender } \\
\text { agreement is reached } \\
\text { before the balance sheet } \\
\text { date. }\end{array}$ \\
\hline $\begin{array}{l}\text { Balance sheet } \\
\text { classification of } \\
\text { deferred tax assets } \\
\text { and liabilities }\end{array}$ & $\begin{array}{l}\text { All deferred tax assets and } \\
\text { liabilities will be classified as } \\
\text { noncurrent. }\end{array}$ & $\begin{array}{l}\text { All amounts classified as } \\
\text { noncurrent in the balance } \\
\text { sheet. }\end{array}$ \\
\hline $\begin{array}{l}\text { Income statement- } \\
\text { classification of } \\
\text { expenses }\end{array}$ & $\begin{array}{l}\text { There is no general requirement } \\
\text { within the US GAAP to classify } \\
\text { the income statement items by } \\
\text { function or nature although } \\
\text { there are requirements based }\end{array}$ & $\begin{array}{l}\text { Entities may present } \\
\text { expenses based on either } \\
\text { function or nature (e.g., } \\
\text { salaries, depreciation). } \\
\text { However, if function is }\end{array}$ \\
\hline
\end{tabular}




\begin{tabular}{|c|c|c|}
\hline & $\begin{array}{l}\text { on the specific cost incurred } \\
\text { (e.g. restructuring fees and } \\
\text { freight and handling costs). } \\
\text { However, SEC registrar is } \\
\text { generally required to provide } \\
\text { expenses based on the post } \\
\text { (e.g., cost of sales, } \\
\text { management). }\end{array}$ & $\begin{array}{l}\text { selected, certain } \\
\text { disclosures about the } \\
\text { nature of expenses must } \\
\text { be included in the notes. }\end{array}$ \\
\hline $\begin{array}{l}\text { Income statement- } \\
\text { discontinued } \\
\text { operations criteria }\end{array}$ & $\begin{array}{l}\text { Discontinued operations } \\
\text { classification is for components } \\
\text { that are: Held for sale or } \\
\text { disposed of and represent a } \\
\text { strategic shift that has (or will } \\
\text { have) a major effect on an } \\
\text { entity's operations and financial } \\
\text { results. Also a newly acquired } \\
\text { business or nonprofit activity } \\
\text { that on acquisition is classified } \\
\text { as held for sale qualifies for } \\
\text { reporting as a discontinued } \\
\text { operation. }\end{array}$ & $\begin{array}{l}\text { Discontinued operations } \\
\text { classification is for } \\
\text { components held for sale } \\
\text { or disposed of and the } \\
\text { component represents a } \\
\text { separate major line of } \\
\text { business or geographical } \\
\text { area, is part of a single } \\
\text { coordinated plan to } \\
\text { dispose of a separate } \\
\text { major line of business or } \\
\text { geographical area of or a } \\
\text { subsidiary acquired } \\
\text { exclusively with an } \\
\text { intention to resell. }\end{array}$ \\
\hline $\begin{array}{l}\text { Statement of cash } \\
\text { flows-restricted } \\
\text { cash }\end{array}$ & $\begin{array}{l}\text { Statement of Cash Flows- } \\
\text { Restricted Cash, changes in } \\
\text { restricted cash and restricted } \\
\text { cash equivalents will be shown } \\
\text { in the statement of cash flows. } \\
\text { In addition, when cash, cash } \\
\text { equivalents, restricted cash and } \\
\text { restricted cash equivalents are } \\
\text { presented in more than one-line } \\
\text { item on the balance sheet, also } \\
\text { it requires a reconciliation of the } \\
\text { totals in the statement of cash } \\
\text { flows to the related captions in } \\
\text { the balance sheet. This } \\
\text { reconciliation can be presented } \\
\text { either on the face of the } \\
\text { statement of cash flows or in } \\
\text { the notes to the financial } \\
\text { statements. }\end{array}$ & $\begin{array}{l}\text { There is no specific } \\
\text { guidance about the } \\
\text { presentation of changes } \\
\text { in restricted cash and } \\
\text { restricted cash } \\
\text { equivalents on the } \\
\text { statement of cash flows. }\end{array}$ \\
\hline $\begin{array}{l}\text { Disclosure } \\
\text { performance } \\
\text { measures }\end{array}$ & $\begin{array}{l}\text { There are no general } \\
\text { requirements within US GAAP } \\
\text { address the presentation of } \\
\text { specific performance measures. } \\
\text { SEC regulations define certain } \\
\text { key measures and require the } \\
\text { presentation of certain headings }\end{array}$ & $\begin{array}{lr}\text { Certain } & \text { traditional } \\
\text { concepts such as } & \text { such are not } \\
\text { "operating profit" are not } \\
\text { defined; therefore, } \\
\text { diversity in practice exists } \\
\text { regarding line items, } \\
\text { headings and subtotals }\end{array}$ \\
\hline
\end{tabular}




\begin{tabular}{|c|c|c|}
\hline & $\begin{array}{l}\text { and subtotals. Additionally, } \\
\text { public companies are prohibited } \\
\text { from disclosing non-GAAP } \\
\text { measures in the financial } \\
\text { statements and accompanying } \\
\text { notes. }\end{array}$ & $\begin{array}{l}\text { presented on the income } \\
\text { statement. IFRS permits } \\
\text { the presentation of } \\
\text { additional line items, } \\
\text { headings and subtotals in } \\
\text { the statement of } \\
\text { comprehensive income } \\
\text { when such presentation is } \\
\text { relevant to an } \\
\text { understanding of the } \\
\text { entity's financial } \\
\text { performance. IFRS has } \\
\text { requirements on how the } \\
\text { subtotals should be } \\
\text { presented when they are } \\
\text { provided, }\end{array}$ \\
\hline $\begin{array}{l}\text { Third balance } \\
\text { sheet }\end{array}$ & Not required. & $\begin{array}{l}\text { A third balance sheet is } \\
\text { required as of the } \\
\text { beginning of the earliest } \\
\text { comparative period when } \\
\text { there is a retrospective } \\
\text { application of a new } \\
\text { accounting policy, or a } \\
\text { retrospective restatement } \\
\text { or reclassification, that } \\
\text { have a material effect on } \\
\text { the balances of the third } \\
\text { balance sheet. Related } \\
\text { notes to the third balance } \\
\text { sheet are not required. A } \\
\text { third balance sheet is also } \\
\text { required in the year an } \\
\text { entity first applies IFRS. }\end{array}$ \\
\hline
\end{tabular}

Source: US GAAP versus IFRS The basics January 2021. Available: https://www.ey.com/en us/assurance/accountinglink/us-gaap-versus-ifrs--the-

basics---january-2021

\section{Research Methodology}

In order to keep in mind the reliability and accuracy of the research data, this research method has been selected in a critical manner. Firstly, manner is a qualitative approach, in order to get some reliable and accurate data to be collected, interpreted, and reported in this research paper, the qualitative data will be collected through a practical case study, which will allow us to understand the deep application, results, and consequences of the different standards being adopted by the company. This case study, which is taken from a real company based in Norway and called Hydro. A company was using US GAAP standards in their accounting system, and in 2006 they decided to switch to IFRS standards, this case study helps to collect real data from the company published and shared 
financial statements under IFRS and then compare them to the results of the same financial information under US GAAP standards.

\section{Case Study}

It is critical for the reader to have a thorough grasp of the differences between US GAAP and IFRS. The need to understand both US GAAP and IFRS. This research chooses Hydro 2007 as a case study to explain the differences between both standards. Hydro published enough financial information in public which allows for a full comparison.

The below figures show the difference between both standards in real numbers. When comparing US GAAP to IFRS income statements (Figure 1), there are variations in presentation and categorization. The term "operating revenue" is replaced by the term "revenue." Operating revenues under US GAAP contain several miscellaneous revenue components that are categorized as other income, net under IFRS. The line-item Share of the profit (loss) from equity-accounted investments is now included as part of Total revenue and income. The amount of Share of the profit (loss) from equity-accounted investments is different after the presentation change as discontinued operations are included in the amount; IFRS does not have line-item Discontinued operations in the financial statements. The line-item other income, net, comprises some miscellaneous revenue items and gain or loss on sale of property, plant and equipment, and investments previously reported as part of Other operating expenses.

\begin{tabular}{|l|r|r|}
\hline & US GAAP & IFRS \\
\hline Operating revenues & 196,234 & \\
\hline Revenue & 201,283 \\
\hline Share of the profit (loss) in equity accounted investments & 990 \\
\hline Other income, net & 1,470 \\
\hline Total revenue and income & \\
\hline Raw material and energy expense & 98,961 & 82,810 \\
\hline Employee benefits expense / Payroll and related costs & 19,404 & 19,546 \\
\hline Depreciation and amortization expense & 16,937 & 17,215 \\
\hline Impairment of non-current assets / Impairment losses & 5,228 & 5,492 \\
\hline Other & 3,481 & 23,670 \\
\hline Total expenses / Operating costs and expenses & 144,010 & 148,733 \\
\hline Operating income & 52,224 & \\
\hline Earnings before financial items and tax & 55,010 \\
\hline Financial income (expense), net & 1,785 & \\
\hline Financial income & 1,425 \\
\hline Financial expense & $(43)$ \\
\hline Financial income (expense), net & 1,785 & 1,382 \\
\hline Equity in net income of non-consolidated investees & 962 & \\
\hline Other income (expense), net & 53 & \\
\hline Income before tax / Income from continuing operations before taxes and minority interest & 55,024 & 56,392 \\
\hline Income tax expense & $(37,598)$ & $(38,459)$ \\
\hline Minority interest & $(202)$ \\
\hline Income from continuing operations & 17,224 & 167 \\
\hline Income from discontinued operations & 17,391 & 17,933 \\
\hline Net income & 273 \\
\hline Net income attributable to minority interests & 17,660 \\
\hline Net income attributable to equity holders of the parent & \\
\hline Fla & \\
\hline
\end{tabular}

Figure 1: Consolidated income statement US GAAP to IFRS

Source: www.hydro.com 


\begin{tabular}{|c|c|c|}
\hline & US GAAP & IFRS \\
\hline \multicolumn{3}{|l|}{ Assets } \\
\hline Cash and cash equivalents & 6,760 & 6,760 \\
\hline Short-term investments & 15,020 & 15,020 \\
\hline Accounts receivable & 25,608 & 34,508 \\
\hline Inventories & 16,497 & 16,497 \\
\hline Other current assets / Prepaid expenses and other current assets & 14,025 & 7,980 \\
\hline Current deferred tax assets & 3,099 & \\
\hline Assets held for sale / Current assets held for sale & 1,122 & 3,691 \\
\hline Total current assets & 82,131 & 84,457 \\
\hline Investments accounted for using the equity method/non-consolidated investees & 10,455 & 10,690 \\
\hline Property, plant and equipment & 124,976 & 119,075 \\
\hline Intangible assets & 4,861 & 11,475 \\
\hline Financial assets & & 4,914 \\
\hline Other non-current assets / Prepaid pension, investments and other non-current assets & 7,763 & 303 \\
\hline Deferred tax assets & 1,239 & 2,177 \\
\hline & 2,569 & \\
\hline Total non-current assets & 151,862 & 148,635 \\
\hline Total assets & 233,993 & 233,092 \\
\hline \multicolumn{3}{|l|}{ Liabilities and equity } \\
\hline Trade and other payables & & 29,785 \\
\hline Bank loans and other interest-bearing short-term debt & 3,213 & 3,655 \\
\hline Current portion of long-term debt & 441 & \\
\hline Provisions & & 2,197 \\
\hline Taxes payable & & 18,995 \\
\hline Other current liabilities & 55,550 & 7,949 \\
\hline Current deferred tax liabilities & 1,134 & - \\
\hline Liabilities included in disposal groups / Current liabilities in disposal groups & 738 & 1,011 \\
\hline Total current liabilities & 61,076 & 63,591 \\
\hline Long-term debt & 19,619 & 19,619 \\
\hline Provisions & & 14,357 \\
\hline Pension obligation & 12,391 & 12,605 \\
\hline Other financial liabilities & & 353 \\
\hline Other liabilities & 16,126 & 2,702 \\
\hline Deferred tax liabilities & 27,307 & 23,265 \\
\hline Long-term liabilities in disposal groups & 273 & \\
\hline Total non-current liabilities & 75,715 & 72,900 \\
\hline Total liabilities & & 136,491 \\
\hline Minority shareholders' interest in consolidated subsidiaries & 707 & \\
\hline Share capital & 4,708 & 4,708 \\
\hline Additional paid-in capital & 9,736 & 9,736 \\
\hline Other reserves / Accumulated other comprehensive income (loss) & $(9,135)$ & $(1,533)$ \\
\hline Retained earnings & 97,811 & 89,544 \\
\hline Treasury shares & $(6,624)$ & $(6,624)$ \\
\hline Equity attributable to equity holders of the parent / Shareholders' equity & 96,496 & 95,831 \\
\hline Minority interest & & 771 \\
\hline Total equity & & 96,601 \\
\hline Total liabilities and equity / shareholders' equity & 233,993 & 233,092 \\
\hline
\end{tabular}

Figure 2: Consolidated balance sheet US GAAP to IFRS

Source: www.hydro.com

When comparing US GAAP to IFRS income statements (Figure 1), there are variations in presentation and categorization. The term "operating revenue" is replaced by the term "revenue." Operating revenues under US GAAP contain several miscellaneous revenue components that are categorized as other income, net under IFRS. The line item Share of the profit (loss) from equity accounted investments is now included as part of Total revenue and income. The amount of Share of the profit (loss) from equity accounted investments is different after the presentation change as discontinued operations are included in the amount; IFRS does not have a line item Discontinued operations in the financial statements. The 
line item Other income, net, comprises some miscellaneous revenue items and gain or loss on sale of property, plant and equipment and investments previously reported as part of Other operating expenses.

When it comes to Balance Sheet (Figure 2), short-term receivables that were formerly categorized as part of other current assets under US GAAP are now classified as Accounts Receivable. VAT receivables and other external prepaid goods make up most of these short-term receivables. Under US GAAP, capitalized exploration costs were classed as part of Property, plant, and equipment, but are now classified as intangible assets. Non-current financial assets have been reclassified from other non-current assets and are now shown on the face of the balance sheet. Shares held for trading are classified as part of Short-term investments with a fair value. Non-marketable shares previously classified under US GAAP as not held for trading are classified as available-for-sale under IFRS with changes in fair value booked against equity. The shares are presented in the balance sheet as part of Financial Assets. Non-marketable shares in the US GAAP balance sheet were classified as prepaid pension, investment and other noncurrent assets, and measured at cost.

The IFRS statement of cash flows is very similar in presentation and format to the US GAAP statement of cash flows, with only four presentation, classification or measurement differences related to them measurement of cash, Classification of capitalized interest, presentation of capitalized capital maintenance and presentation related to Assets held for sale.

\section{Conclusion}

This study aimed to study the main differences between US GAAP and IFRS when it comes to financial statement presentation. The study used a real-life case study to compare both standards applications. Findings of the study comprised that there are many similarities between US GAAP and IFRS when it comes to the presentation of financial statements. Even with these similarities, the differences are still recognizable and effective to the results of the financial statements. This study examined the main differences between US GAAP and IFRS in financial statements presentation. The finding of this research concluded that there is a significant difference in presenting financial data between US GAAP and IFRS, the main differences were in the income statement and balance sheet. For example, US GAAP doesn't require a third balance sheet while IFRS requires it in specific conditions. While the statement of cash flows is very similar in presentation and format in IFRS to the US GAAP. Finally, In the case study, coverage of IFRS methodology is addressed, and the most likely financial statement differences between US GAAP and IFRS are examined and listed which approves the differences between both accounting systems.

\section{References:}

1. AICPA, 2021. History of the AICPA. [Online] Available at: https://www.aicpa.org/about/missionandhistory/history-of-the-aicpa.html [Accessed 2021].

2. Burlaud, A. \& Baker, R., 2015. Epistemology of accounting: from doctrine to consequentialism. French Accounting Review,.

3. EY, 2021. US GAAP versus IFRS The basics, s.I.: s.n. 
4. FASB, 2021. Financial Accounting Standards Board. [Online] Available at: https://www.fasb.org/facts/

5. Gibson, C. H., 2009. Financial Reporting \&Analysis: Using Financial Accounting Information. s.I.:The University of Toledo, Emeritus.

6. Gordon, E. A., Jorgensen, B. N. \& Linthicum, C. L., 2011. Could IFRS Replace US GAAP? A Comparison of Earnings Attributes and Informativeness in the US Market. Working Papers 0028.

7. Hydro, 2007. Norsk Hydro ASA, Oslo: s.n.

8. IASB, 2021. [Online] Available at: https://www.ifrs.org/about-us/who-weare/\#history

9. Pierre, D. \& Guillaume, O., 2016. The Convergence of U.S. GAAP with IFRS: A Comparative Analysis of Principles-based and Rules-based Accounting Standards, s.l.: Scholedge International Journal of Business Policy and Governance.

10. Smith, M., 2011. IFRS and U.S. GAAP: Some key differences accountants should know.

11. Smith, M., 2012. IFRS and U.S. GAAP: Some Key Differences Accountants Should Know. Management Accounting Quarterly, 14(1), pp. 19-26.

12. U. N., 2008. INTERNATIONAL ACCOUNTING and REPORTING ISSUES. New York and Geneva, UNITED NATIONS.

13. Unegbu, A. O., 2014. Theories of Accounting: Evolution \& Developments, IncomeDetermination and Diversities in Use. Research Journal of Finance and Accounting, 15(19). 